\title{
MANAGEMENT OF EDUCATIONAL TECHNOLOGY IMPLEMENTATION IN LEARNING PRAXIS
}

\author{
Budiyono, Haryono, Niam Wahzudik. \\ Curriculum and Educational Technology Department, Faculty of Education, \\ Semarang State University. Semarang, Indonesia
}

\begin{abstract}
The purpose of this research program is to describe the management of educational technology implementation in learning praxis. This research was conducted by using survey research design. The research was conducted in Senior/Vocational High School located in six regencies / cities in Central Java province with teachers and principals as samples. The data were collected by questionnaire, interview, and field observation. Data analysis was done using descriptive qualitative and quantitative approach. The results showed that teachers have known and understood the concept and application of educational technology through various information media. Teachers have various skills in applying educational technology. The appropriateness of educational technology from philosophical dimension and pragmatic value is seen from the effort of developing a quality culture shows that not all schools have policies, procedures or team/ guarantor of quality in schools, which based on the concept and applied education technology.
\end{abstract}

Keywords: management; implementation of educational technology; learning praxis

The development of the community's aspiration level toward education, education supporting science, as well as information and communication technology, encourage people to require the more effective, efficient, massive, and easy learning. This confirms the urgency of educational technology in education. Even the concepts, principles, prepositions, and theses built on the science of educational technology have influenced the principles of learning based on the 2013 curriculum. Educational technology can be understood from product, process, and value dimensions. From the dimensions of product, educational technology is interpreted as the application of technology products in education at simple, medium, and complex stages. The simple stage includes whiteboard, chart, real object, and simple models. While the medium one includes OHP, projection slide, projection film, LCD, and so on. The complex one are such as distance learning using radio, television, modules, computer-assisted learning (CAL), learning with dial-access telephone information systems such as web-based learning and e-learning.

From the process dimension, the definition of educational technology is more focused on the development of the learning experience content that is organized by applying science approach to the importance of organizing educational programs (Romiszoski 1989: 40). The development of systematic learning experiences, various sources of learning in the form of people, materials, tools, techniques, and settings are utilized. Technology products in accordance with its level of development, it is one of the learning resources that can be utilized to be able to provide learning experiences to learners.

The understanding of educational technology from product and process dimensions is an approach to interpreting educational technology in terms of engineering (Bern 1961: 6; Szabo 1968: 23 in Januszewski 2001: 10). Educational technology is a systematic effort in the application of science to provide a learning experience to learners maximally through 
program development and utilization of technology products. The engineering process in the industrial world has enabled the production of more, with better quality, and with lower unit costs. Learning is done through the process of designing, development, source utilization, role sharing, and good control system, is expected to produce more qualified and value-added outcomes.

While the implementation of educational technology in school learning is still considered as problematic in the sense that there is still a gap between what is real (das sein) and how it should be (das sollen). The field praxis shows that the implementation of educational technology is more personal, in the sense of relying solely on the initiative of teachers. There is not unit or section at schools that is responsible for managing the implementation of education technology in it properly. The implementation of personal education technology has not been fully implemented in accordance with the essence, philosophy, and ultimate goal. There are educators who apply educational technology just to meet the interests of his personal ego, such as to assist in the presentation of teaching materials or simply meet the prestige alone (Haryono 2008: 8). In other contexts educational technology is applied without a correct philosophical basis, but rather based on arrogance of technical skills alone so that there are neglected pedagogical ethical values (Haryono 2008: 9). This fact provides reinforcement that educational technology implementation in learning is not enough to rely solely on the availability of inherent hardware and software, but also requires the involvement of intellectual devices (brain ware) of interested subjects.

The classic reason for the weak implementation of educational technology in learning is correct, among others; the teachers feel that they have less time. Their time has been spent on administrative activities and learning process. The implication, they feel that there needs to be a party that helps in the implementation of educational technology so that the learning process runs optimally. With regard to that, it is deemed necessary to have a special agency that can be in charge of managing, guarding, or giving direction about the implementation of educational technology in schools appropriately and efficiently to improve the quality of learning.

Based on the implementation reality, it is necessary that the institution/ unit/ section in the school is responsible for managing learning resources (libraries, laboratories and the environment), managing and developing multi-media learning (including simple media, audio, video, for learning), ensuring the quality of the learning process (according to process standards), even the development and fostering of the school curriculum. While the current principal activities of the school are recognized since 1975 formally, there are only three namely learning, administration, and counseling guidance. Thus if the research is successful and the relevant policy is taken then the domain of school activity are no longer only three as mentioned above, but there will be four of them, namely; learning, administration, counseling, and education technology.

In other respects, there is now a Regulation from the Minister for Administrative Reform No: Per/2/M.Pan/3/2009 concerning the Functional Position of the Learning Technology Developer and its Credit Score. Based on this rule, it appears that the functional position of educational technology developer has a clear legal umbrella. In addition, this regulation provides an opportunity to units, institutions, or other designations under the Ministry of Education and Culture, including schools, to appoint Civil Servants in their functional positions.

Substantive and empirical research proves that the application of educational technology in terms of both applied 
technology products in education (especially learning) as well as systemic processes to address human learning problems significantly improves the quality and performance of learning. The studies were conducted to examine the extent of applied educational technology and that it is able to contribute in improving the quality of learning that leads to achievement of learning outcomes in a more meaningful way.

In this case, research on the implementation of educational technology is differentiated into: a) product development, b) process of using the product, or c) management context. In the world of research, these categorizations are often incomplete, as there are a number of studies that constitute partial parts of the two or three categories.

From the dimensions of the product, many studies prove that the use of educational technology as a product can improve the quality of learning. This can be seen for example in Sie's research, et.all. (2013), there are 7 factors that influence professional learning through personal twitter network, namely; knowledge sharing, motivation, acceptance of network value, feedback, personal learning, trust and support, as well as character and peer values. In addition, differences in perspective, motivation, social media and collaboration, reciprocity, intrinsic motivation, innovation, status and reputation, as well as network strategy play an important role in motivation. While Thuman \& Persson (2013) state that there are significant differences in age and school organization, and tend to differ between public and private schools. Simsek also studied the aspect of creating from different aspects. Simsek (2011) argued that elementary students are less anxious than Junior High School and male students have lower anxiety scores than female. Differences in anxiety scores between teachers and students were not significant. Li, Bado, Smith \& Moore (2013) further examine the number of words in the blog that contain critical and uncritical thinking indicators obtained by students before and after peer comment are no different (mean 206,64 and 185,36 shows no significant difference. Likewise, 194 and 192 are not significantly different as well). The results of interview surveys and focus groups also show similar results.

Handoyo and Asy'ari (2011) also did the Educational Technology study in the domain of creating different aspects in learning context. They studied the utilization of the surrounding environment as a science-learning laboratory in the development of multi intelligence of Primary School Teacher Training students. The research conducted by Bahagia (2011) on improving learning outcomes through cooperative learning by using jigsaw model with visual aids in 5th grader students. Nadlah's (2012) study on the role of real-life media (living things) with corkboard variation can improve the outcomes of learning spermatophyte (seed).

There are also a lot more applied research of educational technology from process dimension. Haryono (1997) has developed a model of learning process characterized by the enhancement of creative and critical thinking skills that significantly improves the creative thinking and critical thinking of elementary students in Central Java. Haryono (2006) also developed a sciencebased learning model of the science process to improve students' science skills that include product, process and attitude dimensions. The development and implementation of mathematics learning design that integrates vocational students' vocational skills development was conducted by Susento (2011). The development of online learning based on the principles of e-pedagogy by Nugraha (2011). Yang \& Li (2013) conducted a study to test the relative effectiveness of two different modes of learning: a computer animation self-directed learning approach and a paper version of the self- 
directed learning approach. The samples are thirty 5 th graders of public elementary school in South Taiwan. The main finding showed that the computer animation group showed better performance in number sense development. Meanwhile AlDujaily, A.; Kim, j. \& Ryu, H. (2013) examined the design of computer-based learning systems in terms of individual differences of learners in learning activities. This study encourages adaptive e-learning systems to fit individual differences effectively, which allows computer-aided tutorials. Individual characteristic (introvert or extrovert) is very influential on learning activities in adaptive e-learning system.

Substantive and empirical research proves that the application of educational technology both in terms of applied technology products in education (especially learning) as well as in terms of systematic and systemic processes to address human learning problems significantly improves the quality and performance of learning. The studies were conducted to examine the extent of applied educational technology. They are able to contribute in improving the quality of learning that leads to achievement of learning outcomes in a more meaningful way.

The research developed focuses on how appropriate and efficient educational technology can improve the quality of learning in schools and education in general. This study will confirm the extent to which applied educational technology in learning praxis is viewed from the mastery of educational practitioners (in particular)/teachers to the concepts and application of educational technology. The research also focused on the application of educational technology in the product dimensions learning praxis and the appropriateness of applied educational technology from the philosophical and pragmatic value dimensions. From empirical mapping results of this applied educational technology, it is then will be developed into an applied model of educational technology, which is appropriate and efficient for the improvement of learning quality in school.

\section{Research Methodology}

This research is a survey research to conduct empirical study on management of Educational Technology implementation in learning praxis. The research was conducted in Senior/Vocational High School located in 6 (six) regencies/ cities in Central Java province covering Magelang, Kendal, Sragen, Kudus, Purwokerto and Tegal districts with teachers and principals as samples. The data were collected by questionnaire, interview, and field observation. The data analysis was carried out using descriptive qualitative approach.

\section{Results and Discussion}

This research has been carried out in Senior/Vocational High School located in 6 regencies/ cities in central java. This study focuses on the application of appropriate and efficient educational technology to improve the quality of learning in schools and education in general. This study is able to confirm the extent of applied educational technology in the praxis of learning in terms of the mastery of educational practitioners (in particular)/teachers to the concepts and application of educational technology. The research also focused on the application of educational technology in the product dimensions learning praxis and the appropriateness of applied educational technology from the philosophical and pragmatic value dimensions. The results of this study are described as follows.

\section{Teachers understanding on the concept and application of educational technology}

$90 \%$ of teachers say they know and/or understand about educational technology while $10 \%$ say they do not 
understand educational technology. Teachers' understanding of educational technology is achieved through $26 \%$ of lectures, $34 \%$ of training, $5 \%$ of reading books, $25 \%$ through internet browsing and $9 \%$ of other resources e.g. peer activities.

The qualitative data of this research shows the various steps, strategies, ways, and approach done by teachers in designing the learning done through the following steps; (1) knowing/mastering the materials that will be delivered; (2) understanding the students' characters; (3) developing learning strategy; (4) conducting learning assessment /evaluation; (5) looking at the depth of basic competence that is tailored to the characteristics of learners along with the material as well as the method of learning. Confirmed on how teachers sort out and select appropriate media and learning methods in designing general teaching lessons by declaring steps to adjust to learning materials, tailored to the characteristics and facilities of the school, keeping up with current trends and selecting media according to the needs in the basic competence .

The implementation of teachers in classroom learning practices using media and specific learning methods has obtained various information, among others, only a few materials that use media/learning methods are selected in accordance with the needs in supporting the learning process could run well and in accordance with the learning plans. When all classes use the same media and methods in learning, the results are not in accordance with the desired outcome, because of the characteristics of different classes.

Further confirmation shows how the implementation of learning evaluations in class have been done well through various ways such as; taking the value of tasks both individually and in groups, formative tests for each chapter that has been discussed, daily tests, written, practice and assignment, as well as by displaying questions on LCD screen.

\section{The applicability of educational technology in product and process dimensions of learning praxis}

Based on the understanding and knowledge of teachers on educational technology, $19 \%$ of teachers understand that the technology is applied technology products in the field of education, 54\% of teachers understand that educational technology is the development and use of media in education/learning, $25 \%$ of teachers said that educational technology is a systematic process in overcoming learning problems, and $2 \%$ teachers provided other reasons. $26 \%$ of teachers stated that educational technology refers to tools, computers, and/or other used in learning, $54 \%$ of teachers stated that educational technology refers to ways and/or methods to improve learning quality, $18 \%$ expressed that it is a systematic effort to overcome learning problems, and $2 \%$ of teachers said that educational technology points to other things.

Based on the functional aspects of educational technology, this study shows that $18 \%$ of teachers stated that educational technology serves to help facilitate teachers in presenting the subject matter; $14 \%$ of teachers stated that educational technology is useful in helping facilitate students in learning subject matter, $66 \%$ of teachers stated that education technology's function is to improve the quality of the learning process, and $2 \%$ mentioned other functions. Confirming teachers' understanding of the scope or work area of educational technology, it shows that $49 \%$ of teachers stated that educational technology includes design, development, utilization, process assessment, sources, and learning systems, $13 \%$ covers the areas of creation, use and management of processes and learning sources, 34\% stated that it covers the field of utilizing various technology products and making various educational/learning media, and $4 \%$ of 
teachers stated that the education technology includes other fields.

Based on the teacher's understanding aspect of the purpose of this research, $60 \%$ of teachers stated that educational technology aims to improve the quality of education (learning), 35\% said that it is about developing various patterns of education / learning, 3\% stated that it is able to expand human learning opportunities and $2 \%$ stated other goals in addition to the above three goals.

The ability/skills of teachers in various aspects related to the understanding and application of educational technology shows the following data.

Table 1. Teachers' skills/ability in applying educational technology

\begin{tabular}{|c|c|c|c|c|}
\hline \multirow[t]{2}{*}{ Skills/ability } & \multicolumn{4}{|c|}{ Criteria Percentage } \\
\hline & $\mathrm{R}$ & $\mathrm{C}$ & $\mathrm{S}$ & $\mathrm{T}$ \\
\hline a. Analyzing the students' characteristics & $4 \%$ & $18 \%$ & $56 \%$ & $23 \%$ \\
\hline $\begin{array}{l}\text { b. Formulating the standard of students' learning } \\
\text { outcome }\end{array}$ & $1 \%$ & $17 \%$ & $53 \%$ & $28 \%$ \\
\hline $\begin{array}{l}\text { c. Choosing learning strategy based on the } \\
\text { characteristics of learning material }\end{array}$ & $1 \%$ & $12 \%$ & $60 \%$ & $27 \%$ \\
\hline $\begin{array}{l}\text { d. Choosing media based on the characteristics of } \\
\text { teaching materials }\end{array}$ & $2 \%$ & $17 \%$ & $57 \%$ & $24 \%$ \\
\hline $\begin{array}{l}\text { e. Developing teaching materials to achieve certain basic } \\
\text { competence }\end{array}$ & $2 \%$ & $15 \%$ & $66 \%$ & $16 \%$ \\
\hline f. Using media effectively in learning process & $1 \%$ & $17 \%$ & $56 \%$ & $26 \%$ \\
\hline $\begin{array}{l}\text { g. Creating a learning process that triggers students to be } \\
\text { active }\end{array}$ & $1 \%$ & $10 \%$ & $49 \%$ & $40 \%$ \\
\hline $\begin{array}{l}\text { h. Developing an evaluation that motivates students to } \\
\text { learn }\end{array}$ & $1 \%$ & $9 \%$ & $64 \%$ & $26 \%$ \\
\hline
\end{tabular}

In the implementation of professional duties as a teacher, this research has been able to reveal the activities that have been done by teachers in the application of educational technology. Those are explained in table 2 below.

Table 2. Teachers' activities in applying educational technology

\section{Skills/ability}

a. Identifying the general characteristics of students

b. Identifying the specific skills of each student

c. Identifying students' learning style

d. Determining the standard of students' learning outcome

e. Formulating learning media which is integrated with $\quad 1 \% \quad 13 \% \quad 55 \% \quad 32 \%$ teaching material and strategy

f. Mobilizing students in classroom learning process. $\quad 2 \% \quad 26 \% \quad 47 \% \quad 25 \%$

g. Developing an evaluation system which is fun for $\quad \begin{array}{llll}1 \% & 15 \% & 55 \% & 29 \%\end{array}$ students

h. Evaluating both the learning plan and its application $\quad 1 \% \quad 18 \% \quad 48 \% \quad 33 \%$ 
The qualitative data shows that there are enough learning media in the classroom to support learning practice, especially for images available in the lab, they are well maintained. The school also budgeted funds for media support facilities. For the learning media, each class is facilitated with LCD and Sound system to help the learning process.

There are also adequate learning facilities in schools in general, including school laboratories, school cooperatives, sports facilities, school gardens, etc. Judging from the quality, treatment, and its use, the respondents said that the facilities are adequate for students learning facilities and used accordingly based on their function. They are enough to support the learning, altough there are some spaces that need addition and structuring equipment, generally, the facilities are quite representative, especially the sports facilities. The only absent facility is school garden.

Research data relating to the existence of procedural provisions on the use of facilities, infrastructure and learning media in schools shows that schools have provided procedures for the use of facilities and learning media. There are some procedures such as asking for permission for using certain facilities and reporting back to an officer responsible to take care of the facilities is required in order to minimize damage. However, some respondents stated that some of the new infrastructure facilities have SOP that has to be followed if anyone at school is about to use them.

The research data related to whether classroom-facilitated learning by teachers is supported by the media and specific learning methods shows that classroom learning facilitated by schools is strongly supported by media and learning methods. Yet another reality shows that not all learning uses the media facilities provided by the school. For example, counseling class and tutorial lessons that have incidental nature.

\section{The appropriateness of educational technology implementation from philosophical dimension and pragmatic value}

To reveal the accuracy of teachers in applying educational technology from philosophical dimensions and pragmatic values, it is reviewed based on (1) the basic aspects of educational technology implementation; (2) the development of a culture of quality; (3) the availability of quality policy documents, (4) the availability of quality teaching documents, and (5) the availability of team/ cluster for quality assurance. The research results describe the appropriateness of applied educational technology as follows.

Based on the basic aspect of educational technology implementation that has been adhered to by teachers, it shows that $17 \%$ of teachers implement it based on the desire to facilitate in presenting the subject matter, $40 \%$ of teachers stated that they want to help facilitate the students to learn the subject matter, $40 \%$ stated because of their desire to make the learning process has more quality, and $3 \%$ of teachers stated because of the desires other than the three things above. In relation to the effort of developing a quality culture conducted in each school where the teacher in charge of this research showed $5 \%$ of teachers stated there is no development of quality culture, $3 \%$ stated that the effort of developing new quality culture discourse has only been conducted in the respective respondent school environment, $20 \%$ of teachers stated that the development of culture quality is being planned, and $72 \%$ of teachers state that quality culture development efforts have been implemented in the school institutions where the respective teachers teach. 
In relation to the availability of a general quality policy document as an effort to develop a general quality culture, the research was able to show $5 \%$ of teachers stated that there was no document of quality policy in schools, $3 \%$ of teachers stated new quality policy documents were already mentioned, $28 \%$ said it was planned, and $64 \%$ stated that a general quality policy document is available and the document has been developed.

The teacher respondents confirmed the availability of the quality policy document. As much as $3 \%$ of teachers stated that they do not have documents which regulate the quality of learning policy, 4\% said the document was newly mentioned, $22 \%$ admitted it is still in the middle of planned preparation and $72 \%$ of teachers declared that the document of quality policy learning has been implemented and confirm that the school has a document of quality learning policy. Still related to the quality of learning, as many as $8 \%$ of teachers stated that there is no team/cluster for quality assurance. $1 \%$ of teachers stated that the new school discouraged the availability of a team/cluster of quality assurance at school, $17 \%$ of teachers stated that the school is currently planning to form one, and $73 \%$ of teachers stated that the school already has a team/cluster of quality assurance.

\section{Conclusion}

Based on the results of this study, in general, teachers have known and understood the concepts and implementation of educational technology through various media information. Teachers have various skills in applying educational technology. The implementation of teachers in the practice of classroom learning evaluation shows that teachers perform by using written tests, oral tests and assignments. The appropriateness of educational technology from philosophical dimension and pragmatic value can be seen from the effort of developing the culture of quality.
It shows that not all schools have policies, procedures or team/cluster of quality assurance in schools based on the concept and implementation of educational technology.

\section{References}

Al-Dujaily, A. Kim,J.; \& Ryu H. 2013. Am I Extravert or Introvert? Considering the Personality Effect Toward e- Learning System. In Educational Technology and Society vol.16 number 3, 14-27

Handoyo, L.D. dan Asy'ari M. 2011. Pemanfaatan Lingkungan Sekitar Sebagai Laboratorium

Pembelajaran IPA dalam Pengembangan Multi Inteligensi Mahasiswa PGSD. Jurnal Kependidikan Widya Dharma, Volume 22, Nomor 1.16-23

Haryono 2008. Praksis Teknologi Pendidikan dalam Pembelajaran yang Terlupakan, pidato pengukuhan guru besar dalam bidang Teknologi Pendidikan, FIP UNNES

Li, K. Bado, N. Smith, J. \& Moore, D. 2013. Blogging for teaching an Learning: Examination of experience, Attitude, and level of Thinking. In Contemporary Educational

Technology.Vol.4 number 3 172-186.

Nadlah, I. 2012. Peranan Media Benda Nyata (Makhluk Hidup) Divariasikan dengan Papan Gabus dapat Meningkatkan Hasil Belajar Materi Spermatophyta (Tumbuhan Biji). Dalam Jurnal Penelitian Pendidikan, 
Volume 29, Nomor 2. 2337

Nugraha, S.T. 2011. Pengembangan Online Learning Berdasarkan PrinsipPrinsip E-Pedagogi. Dalam Jurnal Kependidikan Widya Dharma, Volume 21, Nomor 2. April 2011.

Permenpan: per/2/M.Pan/3/2009 tentang Jabatan Fungsional Pengembang Teknologi Pembelajaran dan Angka Kreditnya

Romiszowski, A.J. 1989. Designing Instructional System. London: Kogan Page.

Susento. 2011. Pengembangan dan Implementasi Desain Pembelajaran Matematika yang Mengintegrasikan Penumbuhan Kecakapan Vokasional Siswa SMP.Dalam Jurnal Kependidikan Widya Dharma, Volume 22, Nomor 1. 13-21.

Thuman, L. \& Persson, M. 2013 Teachers' Acces to and Use of ICT: An Indicator of Growing Inequety in Swedish School. In Contemporary Educational Technology.vol. 4 number 3 155-171

Yang, D.C. \& Li, M.N. 2013. Assessment of Animated Self- Directed Learning Activities Module for Children Number Sense Development. In Educational Technology and Society vol. 16 number (3) $76-89$ 